\title{
Detecting drug use in adolescents using a 3D simulation program
}

\author{
José A. Carmona, Moisés Espínola, Adolfo J. Cangas \& Luis Iribarne \\ University of Almeria, Spain \\ (Received March 29, 2010; Accepted April 30, 2010)
}

\section{Detectando consumo de drogas en adolescentes mediante un programa de simulación $3 D$}

\begin{abstract}
This work presents a new 3D simulation program, called Mii School, and its application to the detection of problem behaviours appearing in school settings. We begin by describing some of the main features of the Mii School program. Then, we present the results of a study in which adolescents responded to Mii School simulations involving the consumption of alcoholic drinks, cigarettes, cannabis, cocaine, and MDMA (ecstasy). We established a "risk profile" based on the observed response patterns. We also present results concerning user satisfaction with the program and the extent to which users felt that the simulated scenes were realistic. Lastly, we discuss the usefulness of Mii School as a tool for assessing drug use in school settings.
\end{abstract}

KEYWORDS: substance use, Virtual Reality, assessment, mental disorders, students.

RESUMEN: Se presenta en este trabajo un nuevo programa de simulación 3D llamado Mii School y su aplicación para la detección de conductas problemáticas que aparecen en contextos escolares. Comenzamos describiendo algunas de las principales características del programa Mii School. A continuación, se presentan los resultados de un estudio con adolescentes en el cual éstos respondieron a situaciones simuladas de Mii School relacionadas con el consumo de bebidas alcohólicas, tabaco, cannabis, cocaína y MDMA (éxtasis). Se estableció un "perfil de riesgo" fundamentado en los patrones de respuesta observados. Además, se presentan los resultados concernientes a la satisfacción de los participantes con el programa y hasta qué punto los participantes consideraron como realistas las distintas escenas simuladas. Finalmente, se discute la utilidad de Mii School como una herramienta de evaluación de consumo de drogas en contextos educativos.

PALABRAS CLAVE: consumo de sustancias, Realidad Virtual, evaluación, trastornos mentales, estudiantes.

\section{INTRODUCTION}

\section{Applications of Virtual Reality to Education.}

The enormous development that new technologies, such as virtual reality, have experienced in recent years has allowed the emergence of a growing number of studies focusing on applying these technologies in the educational field. 
The use of learning models through $3 \mathrm{D}$ virtual reality has several advantages over traditional methods of teaching, such as the possibility of multimodal learning or facilitation of the transfer of skills learned from one context to another (Freitas \& Neumann, 2009). Thus, as some authors indicate, the learning process using virtual reality takes place in a more practical and less limited form than in traditional approaches based on texts. Hence, the use of video games for performance improvement in the learning process is of particular importance, since they add several advantages to this process, as sometimes has been found in psychological research. Specifically, a study by Kim, Park and Baek (in press) shows that when video games are used in conjunction with certain meta-cognitive strategies, it produces an improvement not only in academic learning, but also game performance itself.

In turn, virtual environments that re-create school contexts have been developed for different purposes, such as the re-creation of virtual classes in order to assess and rehabilitate attention deficits in young people (Rizzo et al. 2001; Adams, Finn, Moes, Flannery \& Rizzo, 2009), computer-based learning environments or the so-called virtual schools which are presented as useful learning tools in the educational field, because they give enormous benefits through the use of virtual environments for teaching, such as improving skills and academic results, as an alternative medium for teaching and learning or expanding education access (Virtanen, 2008; Liu, Jou \& Lee, 2008; Poce, 2008). However there is little research related to the study of these virtual schools and of the computerbased learning technologies (Barbour \& Reeves, 2009; Sigala, 2007; Albano, Gaeta \& Salermo, 2006).

On the other hand, there are few studies focused on the application of virtual reality specifically to the field of mental disorder assessment in students, or of treatment in school settings. For violent behaviour inside a school context, there is a software called FearNot! oriented to treat bullying behaviours. This program re-creates, through 3D simulation, violent situations in the school environment with the objective of learning the consequences of these behaviours so that the student eliminates these types of behaviour in school (Zoll, Enz, Schaub, Aylett \& Paiva, 2006). In addition, other researches have studied the treatment of test anxiety and school phobia through the virtual re-creation of the key situations in which these problems appear (Gutiérrez-Maldonado, Alsina-Jurnet, CarvalloBecíu, Letosa-Porta \& Magallón-Neri, 2007). A more detailed description of recent studies with Virtual Reality and its applications to educational settings can be found in Carmona, Cangas, Espínola \& Iribarne (2011).

In this paper, we present a new virtual reality tool called Mii School, which is a 3D school simulator used by psychology researchers for the detection of drug abuse and bullying in adolescents. The school simulator created is an interactive video game where the players, in this case the students, have to choose the options that best reflect their personalities from among 17 scenes simulated. In previous studies, the Mii School program has shown adequate psychometric properties (Carmona, Cangas, García, Langer \& Zarate, submitted). Specifically, 
Cronbach's $\alpha$ indexes was 0.802 for the Mii School total instrument $(0.736$ for the drug-use dimension). In regard to the construct validity, the factor analysis revealed eight factors for the total Mii School program that together explained $57.26 \%$ of the variance; four factors for drug use (total variance explained: $32.57 \%$ ).

In the present study, we describe the technical features of Mii School and the results, obtained with a sample of secondary education students, regarding the detection of substance use.

\section{DESCRIPTION OF MII SCHOOL SCENES}

During the execution of Mii School, the student watches a total of 17 interwoven scenes addressing different aspects of his or her behaviour related to bullying, drug addiction, family life, capacity for attention in class and integration in social groups. All the information introduced by the student, as well as the choices selected in each one of the scenes, and other data of interest, are stored in a web page format for the later viewing and analysis by the psychology researchers. Background music has been added to the scenes, and audio to the conversations, to achieve more realism. Proper movement of the cameras during the transition of scenes has also been carefully done so the simulation would have the quality of a real movie.

There are a total of 5 scenes that study bullying. In some of them, the student is bullied by his schoolmates, and in others, he becomes the bully. In this way, bullying can be studied from several perspectives. Some concrete cases are also studied, such as the reaction of the student to the explicit violence of physical aggression in the schoolyard to see if he is a mediator or, to the contrary, violent. For each bullying scene, the student can select from a series of choices that always follow a general pattern: feeling indifferent to the bullies, protesting to them, responding ironically, running away in fear, facing up to them, or feeling ashamed.

The student's relationship with his parents is also studied in three scenes: one scene checks the father's behaviour, another, the mother's attitude and a third scene, both behaviours. In the first two scenes, the student gets home much later than the hour agreed upon and checks whether the father or the mother scold him, threaten him or, on the contrary, are indifferent to his undisciplined behaviour. In the third scene, the student gets home after school and feels anxious because he has problems with his studies and the simulation checks whether his parents become involved in his problems or are indifferent to them.

During the 6 drug addiction scenes, the drug offered becomes gradually more dangerous. In the first scene, the student is tempted by his schoolmates to smoke in the school playground during recess. In the second scene, he is invited to drink alcohol while eating a pizza at a friend's house. Afterwards, he is offered a marijuana joint in a park. In the last two scenes, the risk is upped further when his friends offer him much more dangerous drugs, such as cocaine 
or ecstasy (MDMA). The choices that the student can make in the drug addiction scenes also follow a general scheme: usually use, refuse to try the drug, advise friends to stop taking it, use occasionally, or leave because he feels uncomfortable.

Figure 1. Screenshots of drugs scenes in Mii School.

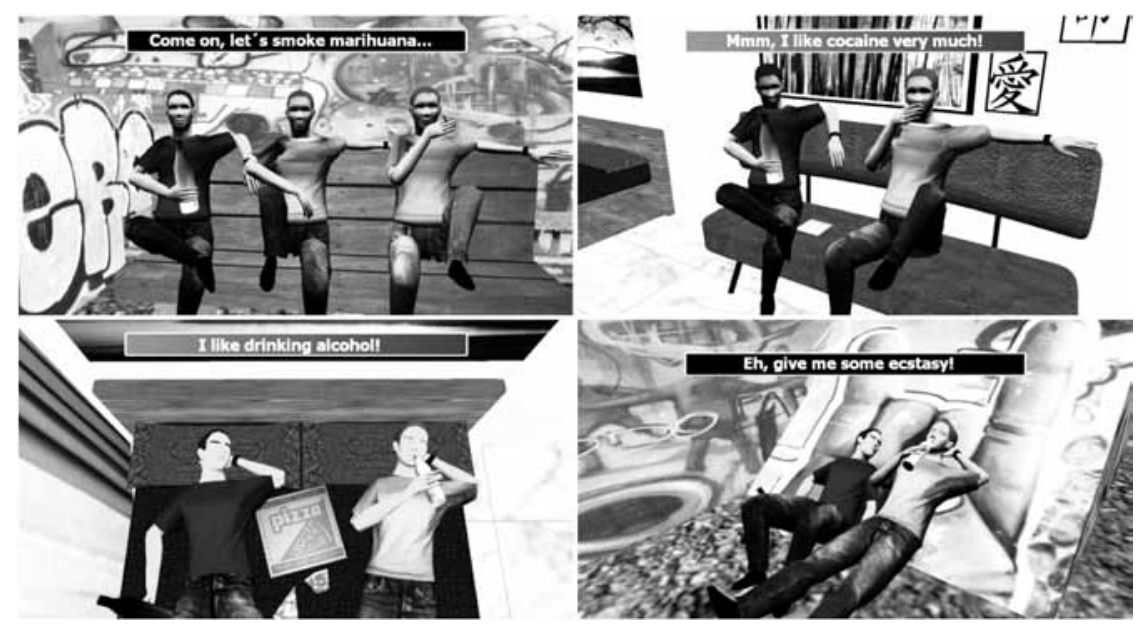

There are other scenes where personality-related problems and the student's mood, attention in class, beliefs and integration in social groups are checked.

\section{METHOD}

\section{Applying Mii-School to the detection of substance use}

This section shows the results of the application of Mii School to a real educational environment. We sought to determine the existence of characteristic profiles of drug use based on participant responses to Mii-School. We also evaluated the participants' level of satisfaction with the general features of the program. Finally, we analyzed the degree of realism that participants attributed to the various scenes in the program related to the detection of drug use.

\section{Participants}

The sample consisted of students from two schools of Compulsory Secondary Education (known in Spain as ESO, equivalent to grades 7 through 10), Baccalaureate (non-compulsory secondary education, equivalent to grades 11 and 12), and vocational training cycles, selected randomly in the province of Almería in Spain (European Union). All the students in these schools participated, in for a total of 570 participants, of which 251 (44.7\%) were male and $310(55.3 \%)$ female ( 9 participants did not report their gender). The distribution of participants 
across years was as follows: 1 st year $\mathrm{ESO}, \mathrm{N}=92 ; 2$ nd year $\mathrm{ESO}, \mathrm{N}=84 ; 3$ rd year $\mathrm{ESO}, \mathrm{N}=101$; 4th year ESO, N=98; 1st year Baccalaureate, $\mathrm{N}=74 ; 2$ nd year Baccalaureate, $\mathrm{N}=47$; vocational training cycles, $\mathrm{N}=22$ (unidentified, $\mathrm{N}=42$ ). The mean age of the participants was 14.93 years $(\mathrm{SD}=2.56)$.

\section{Instruments}

Drug Use Survey of the United Nations Office on Drugs and Crime (2003). This survey was developed by the United Nations to collect information on patterns of drug use, with the aim of comparing patterns of drug use and abuse across countries with a relatively uniform instrument. For the present study, we made slight changes to the survey (as recommended by its original authors) to adapt it to our target population. Specifically, we added the common Spanish names of the various drugs alongside each pharmacological name, to facilitate recognition of the various drugs by the names they possess in their natural contexts. After obtaining personal and demographic information (age, gender, educational level of parents, people living with the participants, etc.) the survey asked participants to report the frequency of drug use, among other things.

Mii School Satisfaction Survey (SS). This survey, developed by the authors of this study, assessed some general Mii School features using a Likert-type scale with 5 response options, ranging from "strongly disagree, never, nothing" to "strongly agree, quite often, always", including the neutral opinion "do not know, no opinion". The survey also measured the realism of the scenes (items) in the virtual simulation by asking participants to report (yes/no) whether they identified themselves with the scenes.

\section{RESULTS}

In this section, we present the responses participants gave in various scenes of the Mii School program, and compare them with the participants' actual drug use as it was reported on the Drug Use Survey. On Mii-School item 2, classmates offer the participant a cigarette in a secluded area of the schoolyard. On Item 4, a friend offers the participant alcohol while the two eat pizza in a house. On Item 8, friends in a park offer the participant a marijuana joint. On Item 9, a friend offers the participant a line of cocaine while they are alone in a house. Finally, on item 15 , the participant is offered MDMA ("ecstasy") on the street. Table 1 shows the responses given by the participants of our study when offered each drug.

For the analyses, we used contingency tables and applied the procedure of corrected typified residuals to determine where statistically significant differences appeared (greater than +1.96 or less than -1.96 ). The percentages in the table marked with a $*$ are statistically significant above +1.96 . 
Table 1. Responses to the Mii-School scenes in which the participants are offered drugs

\begin{tabular}{|c|c|c|c|c|c|c|c|c|c|c|c|}
\hline \multicolumn{12}{|c|}{ ITEMS/SCENES IN MII SCHOOL } \\
\hline \multirow[b]{2}{*}{ RESPONSE } & & \multicolumn{2}{|c|}{ Item 4. Alcohol } & \multicolumn{2}{|c|}{ Item 2. Tobacco } & \multicolumn{2}{|c|}{ Item 8. Cannabis } & \multicolumn{2}{|c|}{ Item 9. Cocaine } & \multicolumn{2}{|c|}{ Item 15. MDMA } \\
\hline & & NO & YES & NO & YES & NO & YES & NO & YES & NO & YES \\
\hline \multirow{2}{*}{ Warning } & Count & 43 & 8 & 49 & 4 & 35 & 2 & 79 & 0 & 95 & 3 \\
\hline & Percentaje & $* 9.8 \%$ & $1.8 \%$ & $* 11.3 \%$ & $0.9 \%$ & $7.6 \%$ & $0.4 \%$ & $17.2 \%$ & $0 \%$ & $21.3 \%$ & $0.7 \%$ \\
\hline \multirow{2}{*}{$\begin{array}{l}\text { Not using } \\
\text { drug }\end{array}$} & Count & 124 & 25 & 210 & 26 & 229 & 8 & 177 & 3 & 159 & 3 \\
\hline & Percentaje & $* 28.2 \%$ & $5.7 \%$ & $* 48.3 \%$ & $6 \%$ & $* 49.8 \%$ & $1.7 \%$ & $38.5 \%$ & $0.7 \%$ & $35.6 \%$ & $0.7 \%$ \\
\hline \multirow{2}{*}{ Using drug } & Count & 13 & 74 & 10 & 49 & 16 & 26 & 8 & 3 & 10 & 2 \\
\hline & Percentaje & $3 \%$ & $* 16.8 \%$ & $2.3 \%$ & * $11.3 \%$ & $3.5 \%$ & $* 5.7 \%$ & $1.7 \%$ & $* 0.7 \%$ & $2.2 \%$ & $* 0.4 \%$ \\
\hline \multirow{2}{*}{ Trying it out } & Count & 62 & 65 & 13 & 11 & 28 & 13 & 13 & 3 & 11 & 2 \\
\hline & Percentaje & $14.1 \%$ & $* 14.8 \%$ & $3 \%$ & $* 2.5 \%$ & $6.1 \%$ & $* 2.8 \%$ & $2.8 \%$ & $*_{0.7 \%}$ & $2.5 \%$ & $* 0.4 \%$ \\
\hline \multirow[t]{2}{*}{ Leaving } & Count & 24 & 2 & 57 & 6 & 101 & 2 & 173 & 1 & 162 & 0 \\
\hline & Percentaje & $* 5.5 \%$ & $0.5 \%$ & $* 13.1 \%$ & $1.4 \%$ & $* 22 \%$ & $0.4 \%$ & $37.6 \%$ & $0.2 \%$ & $* 36.2 \%$ & $0 \%$ \\
\hline
\end{tabular}

When students who reported using drugs on the Drug Use Survey were offered drugs in Mii School, they were more likely to respond by expressing interest in trying and using the substances. On the contrary, students who reported not using drugs were more likely to respond to the Mii School scenes by refusing the offer, warning that using the substance is harmful and even leaving the situation.

We also analyzed the family environment that existed among reported drug users, and the social interactions between the users and their parents. Specifically, two Mii School scenes included in Table 2 refer to the reaction of the father (situation 10) and the mother (situation 11) to a conflict in which the participant did not obey a curfew. A third scene, 12, shows the reaction of both parents together when the participant returns home sad after a bad day at school.

These three scenes were revealed to be statistically significant in predicting users of the substances shown in Table $2(\mathrm{p}<0.05)$.

We found that social interactions between drug users and their parents were more characterized by shouting and indifference on behalf of the parents. On the contrary, we found a significant relationship between non-users and parent reactions of anger and dialogue. Interestingly, we found a significant relationship between cannabis use and having a mother who was open to dialogue when the participant returned home sad from school.

Table 2. Scenes in Mii-School evaluating family relationships

\begin{tabular}{|c|c|c|c|c|c|c|c|c|c|c|c|c|c|c|}
\hline \multicolumn{15}{|c|}{ ITEMS/SCENES IN THE MII SCHOOL PROGRAM } \\
\hline \multirow[b]{2}{*}{ Drug use } & & & \multicolumn{4}{|c|}{ Item 10. Father's reaction } & \multicolumn{4}{|c|}{ Item 11. Mother's reaction } & \multicolumn{4}{|c|}{ Item 12. Parents' reaction } \\
\hline & & & Shouting & Anger & $\begin{array}{c}\text { Open } \\
\text { to } \\
\text { dialogue }\end{array}$ & Indifference & $\begin{array}{l}\text { Shou } \\
\text { ting }\end{array}$ & Anger & $\begin{array}{l}\text { Open } \\
\text { to } \\
\text { dialo } \\
\text { gue }\end{array}$ & $\begin{array}{c}\text { Indi } \\
\text { fferen } \\
\text { ce }\end{array}$ & $\begin{array}{c}\text { Father } \\
\text { open to } \\
\text { dialogue }\end{array}$ & \begin{tabular}{|l} 
Mother \\
open to \\
dialogue
\end{tabular} & \begin{tabular}{|c|} 
Both \\
open to \\
dialogue
\end{tabular} & $\begin{array}{r}\text { Both } \\
\text { indi } \\
\text { fferent }\end{array}$ \\
\hline \multirow{2}{*}{\multicolumn{2}{|c|}{ YES }} & Count & 24 & 41 & 27 & 5 & - & - & - & - & - & - & - & - \\
\hline & & Percentage & $* 5.5 \%$ & $9.4 \%$ & $6.2 \%$ & $1.2 \%$ & - & - & - & - & - & - & - & - \\
\hline
\end{tabular}




\begin{tabular}{|c|c|c|c|c|c|c|c|c|c|c|c|c|c|c|}
\hline \multirow{4}{*}{ Cannabis } & \multirow{2}{*}{ YES } & Count & 19 & 32 & 22 & 7 & 14 & 32 & 24 & 10 & 1 & 35 & 33 & 11 \\
\hline & & Percentage & $* 4.1 \%$ & $7 \%$ & $4.8 \%$ & $1.5 \%$ & $3.1 \%$ & $7 \%$ & $5.2 \%$ & $* 2.2 \%$ & $0.2 \%$ & $* 7.7 \%$ & $7.3 \%$ & $* 2.4 \%$ \\
\hline & \multirow{2}{*}{ NO } & Count & 52 & 151 & 162 & 15 & 62 & 128 & 178 & 11 & 28 & 76 & 244 & 26 \\
\hline & & Percentage & $11.3 \%$ & $32 \%$ & *35.2\% & $3.3 \%$ & $13.5 \%$ & $17.9 \%$ & *38.8\% & $2.4 \%$ & $* 6.2 \%$ & $16.7 \%$ & \begin{tabular}{|l|}
$* 53.7 \%$ \\
\end{tabular} & $5.7 \%$ \\
\hline \multirow{4}{*}{ Cocaine } & \multirow{2}{*}{ YES } & Count & 4 & 1 & 3 & 2 & 1 & 1 & 4 & 4 & - & - & - & - \\
\hline & & Percentage & $* 0.9 \%$ & $0.2 \%$ & $0.6 \%$ & $* 0.4 \%$ & $0.2 \%$ & $0.2 \%$ & $0.9 \%$ & $* 0.9 \%$ & - & - & - & - \\
\hline & \multirow{2}{*}{ NO } & Count & 67 & 183 & 182 & 20 & 75 & 160 & 200 & 16 & - & - & - & \\
\hline & & Percentage & $14.5 \%$ & *39.6\% & $39.4 \%$ & $4.3 \%$ & $16.3 \%$ & $34.7 \%$ & $43.4 \%$ & $3.5 \%$ & - & - & - & - \\
\hline \multirow{4}{*}{ MDMA } & \multirow{2}{*}{ YES } & Count & 1 & 2 & 1 & 2 & \begin{tabular}{|l|}
1 \\
\end{tabular} & 1 & \begin{tabular}{|l|}
1 \\
\end{tabular} & 3 & 0 & 3 & 1 & 2 \\
\hline & & Percentage & $0.2 \%$ & $0.4 \%$ & $0.2 \%$ & $* 0.4 \%$ & $0.2 \%$ & $0.2 \%$ & $0.2 \%$ & ${ }^{*} 0.7 \%$ & $0 \%$ & $0.7 \%$ & $0.2 \%$ & ${ }^{*} 0.4 \%$ \\
\hline & \multirow{2}{*}{ NO } & Count & 70 & 180 & 182 & 20 & 75 & 159 & 200 & 17 & 29 & 108 & 274 & 35 \\
\hline & & Percentage & $15.3 \%$ & $39.3 \%$ & $39.7 \%$ & $4.4 \%$ & $16.4 \%$ & $34.8 \%$ & $43.8 \%$ & $3.7 \%$ & $6.4 \%$ & $23.9 \%$ & $* 60.6 \%$ & $7.7 \%$ \\
\hline
\end{tabular}

Finally, there are two more scenes in Mii School bearing a statistically significant relationship with drug use $(p<0.05)$. Analyses for Item 5 called "in class" revealed a significant relationship between cannabis users and being disinterested during class $(* 3.9 \%)$ and not understanding the teacher $(* 0.6 \%)$. Conversely, non-users of cannabis were more characterized by being attentive during class (*22.9\%). Analyses for Item 6 "in the schoolyard" revealed a significant relationship between cocaine use and staying alone during recess $(* 0.2 \%)$ and feeling different from peers $(* 0.4 \%)$. Non-users of cocaine tended to socialize with classmates in a group during recess $(* 89.7 \%)$.

\section{Scene realism and satisfaction results.}

In this section we present the results of the Mii School Satisfaction Survey (SS), which measured participant satisfaction with the general features of the Mii School program.

As seen in Table 3, a high percentage of participants gave a positive assessment of the program. Previous studies have found similar results in this regard (Carmona, Espínola, Cangas \& Iribarne, 2010). Only one item on the survey did not receive high approval, the item referring to familiarity with Mii School and this type of technology.

Table 3. Satisfaction of Mii School users

\begin{tabular}{|l|c|}
\hline \multicolumn{1}{|c|}{ ITEMS } & $\%$ students \\
\hline It was easy to identify the subject (drugs, bullying) of each scene & $85.3 \%$ \\
\hline $\begin{array}{l}\text { The instructions provided by the program are enough to understand } \\
\text { how it works }\end{array}$ & $90.4 \%$ \\
\hline \begin{tabular}{l} 
I found it easy to use the response system used by the program \\
\hline $\begin{array}{l}\text { Each scene's information (dialogue, interactions, etc) was enough to } \\
\text { understand the situation described in the scene }\end{array}$
\end{tabular} & $86 \%$ \\
\hline
\end{tabular}




\begin{tabular}{|l|c|}
\hline The playing time of each scene was enough to understand its content. & $82.9 \%$ \\
\hline $\begin{array}{l}\text { The playing time of the responses was enough to clearly recognize } \\
\text { the response options available }\end{array}$ & $81.9 \%$ \\
\hline $\begin{array}{l}\text { I found familiar the use of Mii School, given that I am used to these } \\
\text { technologies }\end{array}$ & $57 \%$ \\
\hline $\begin{array}{l}\text { I found using the program to be very attractive (entertaining, funny, } \\
\text { interesting) }\end{array}$ & $71.5 \%$ \\
\hline $\begin{array}{l}\text { In general, Mii School situations are appropriate for evaluating the } \\
\text { issues in each scene. }\end{array}$ & $81.7 \%$ \\
\hline
\end{tabular}

Finally, we assessed the realism of the Mii School scenes addressing drug use. The following figure shows the percentage of participants who reported that the scenes involving drug use, family relationships, and social relationships were realistic.

Figure 2. Realism of the scenes simulated in Mii School

\section{Realism of the screens}

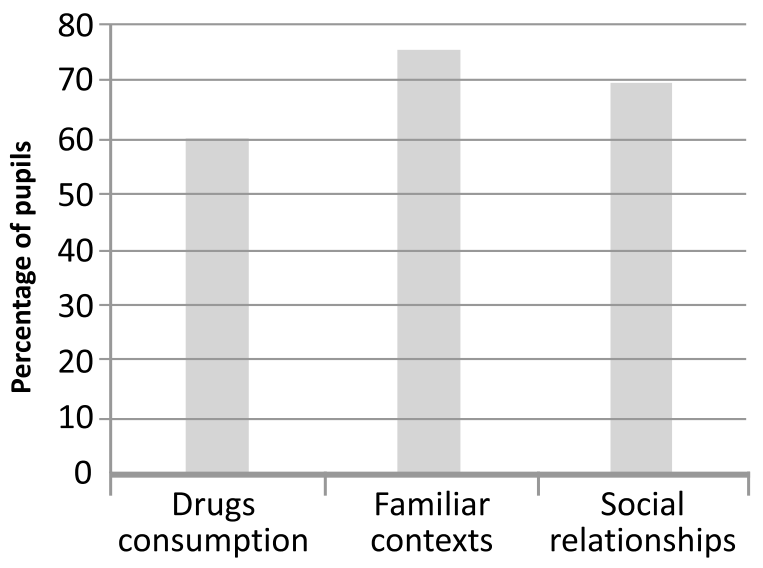

As shown in the figure, the participants of this study believed the most realistic scenes were those involving the family context, (75.7\% of the students), followed by those involving every day social relationships (68.9\%) and drug use $(59.32 \%)$.

\section{DISCUSSION}

The application of new technologies such as virtual reality to the assessment and treatment of psychological problems is growing ever more relevant, due to the advantages these technologies provide in many applied areas, including the 
study of disorders connected to educational settings. We have described an assessment tool called Mii School that is geared toward detecting problem behaviours in adolescents. Mii School is a program that uses 3D graphics similar to modern video games to re-create school, family, and leisure situations in which adolescents may engage in drug use and other problem behaviours.

We have presented the results regarding the responses of adolescent participants to this program connected to drug use. The results suggest that when substance users are offered substances, they are more likely to respond by trying and using the substance. On the contrary, when non-users are offered substances, they characteristically respond by refusing, together with warning the people offering the drug about its harmful effects, or leaving the area where the drug users are situated. Regarding the family context, the parents of drug users are more likely to respond to conflict situations with their children by shouting and expressing indifference toward the situation. Regarding everyday social situations at school, cocaine users are characterized by preferring to be alone or away from their peers during recess, and by feeling different from their peers. In class, cannabis user are characterised by being uninterested and not understanding the explanations of the teacher. We believe this response pattern may serve as a "risk profile" for substance use in adolescents. The difference in the response patterns of users and non-users was revealed by a virtual re-creation of these types of situations.

The fact that the Mii School program was rated positively by a high percentage of the participants in our study suggests that use of Mii School or, generally, this type of $3 \mathrm{D}$ technology, may be ideal when studying young people, given that these types of programs are appealing, widely used, and accepted in this population.

In short, Mii School appears to be a useful application of 3D technology to observe how adolescents respond to simulations of real-life problems. Such technology could be used in schools as a form of drug screening to detect users or those at risk. It could also serve as an educational tool to combat these issues in school settings (Carmona, Espínola, Cangas \& Iribarne, in press; Botella, García-Palacios, Baños \& Quero, 2007). Some limitations of this study are that reported drug use was not corroborated with biochemical testing, and that the sample was limited to only two schools.

\section{Acknowledgments}

This work was financed with a research project from the SPANISH MINISTRY OF HEALTH AND CONSUMPTION (NATIONAL PLAN ON DRUGS, ref. 2007/063) awarded to the third author.

\section{REFERENCES}

Adams, R., Finn, P., Moes, E., Flannery, K. \& Rizzo A.S. (2009). Distractibility 
in Attention/Deficit/Hiperactivity Disorder (ADHD): the Virtual Reality classroom. Child Neuropsychology, 15, 120-135.

Albano, G., Gaeta, M. \& Salermo, S. (2006). E-learning: a model and process proposal. International Journal of Knowledge and Learning, 2, 73-88.

Barbour, M. K. \& Reeves, T. C. (2009). The reality of virtual schools: A review of the literature. Computers \& Education, 52, 402-416.

Botella, C., García-Palacios, A., Baños, R.M. \& Quero, S. (2007). Realidad Virtual y Tratamientos Psicológicos. Cuadernos de medicina psicosomática y psiquiatría de enlace, 82, 17-31.

Carmona, J. A., Cangas, A. J., García, G. R., Langer, A. I. \& Zárate, R. (2010). Early Detection of Drug Use and Bullying in Secondary School Children Using a 3-D Simulation Program. Manuscript submitted for publication.

Carmona, J. A., Cangas, A. J., Iribarne, L. \& Espínola, M. (2011). Applying virtual reality (VR) to the detection and treatment of clinical problems in educational settings. In P. Ordoñes de Pablos, J. Zhao \& R. Tennyson (eds.). Technology Enhanced Learning for People with Disabilities: Approaches and Applications (pp. 194-202). Hershey: Information Science Reference.

Carmona, J. A., Espínola, M., Cangas, A. J. \& Iribarne, L. (in press). Mii-School: A 3D videogame for the early detection of abuse of substances, bullying and mental disorders in adolescents. European Journal of Education and Psychology.

Carmona, J. A., Espínola, M., Cangas, A.J. \& Iribarne, L. (2010). Mii School: New 3D Technologies Applied in Education to Detect Drug Abuses and Bullying in Adolescents. In M. D. Lytras, et al. (Eds.). Technology Enhanced Learning: Quality of Teaching and Educational Reform (pp. 65-72). Heidelberg: Springer.

Freitas, S. \& Neumann, T. (2009). The use of 'exploratory learning' for supporting immersive learning in virtual environments. Computers \& Education, 52, 343-352.

Gutiérrez-Maldonado, J., Alsina-Jurnet, I., Carvallo-Becíu, C., Letosa-Porta, A. \& Magallón-Neri, E. (2007). Aplicaciones clínicas de la realidad virtual en el ámbito escolar. Cuadernos de Medicina Psicosomática y Psiquiatría de Enlace, 82, 32-51.

Kim, B., Park, H. \& Baek, Y. (in press). Not just fun, but serious strategies: Using meta-cognitive strategies in game-based learning. Computers \& Education.

Liu, C-C., Jou, M. \& Lee, H-C., (2008). Development of an e-learning system for manufacturing technology education. International Journal of Knowledge and Learning, 4, 370-382.

Oficina de las Naciones Unidas contra la Droga y el Delito (2003). Encuestas escolares sobre el uso indebido de drogas. Nueva York: Naciones Unidas.

Poce, A. (2008). Evaluating innovation in higher education teaching and learning to improve quality: an experience of blended learning at the Universita Roma Tre. International Journal of Knowledge and Learning, 4, 109-126

Rizzo, A. A., Buckwalter, J.G., Bowerly, T., Humphrey, L. A., Neumann, U., 
Rooyen, A. et al. (2001). The virtual classroom: a virtual reality environment for the assessment and rehabilitation of attention deficits. Revista Española de Neuropsicología, 3, 11-37.

Serrano, A. \& Iborra, I. (2005). Violencia entre compañeros en la escuela. España: Goaprint.

Sigala, M., 2007. Integrating Web 2.0 in e-learning environnements: a sociotechnical approach. International Journal of Knowledge and Learning, 3, 628-648.

Virtanen, S., (2008). Increasing the self-study effort of higher education enfineering students with online learning platform. International Journal of Knowledge and Learning, 4, 527-538.

Zoll, C., Enz, S., Schaub, H., Aylett, R. \& Paiva, A., (2006). Fighting bullying with the help of autonomous agents in a virtual school environment. Paper presented in the 7th International Conference on Cognitive Modelling, Trieste, Italy. 